\title{
Gene expression profile of Protamines and Transition Nuclear Proteins in bovine testis
}

\section{Expressão gênica de protaminas e proteínas nucleares de transição em testículos bovinos}

\author{
Marcia de Almeida Monteiro Melo FERRAZ'; Renata SIMÕES²; Flávia de Oliveira BARROS ${ }^{1}$;

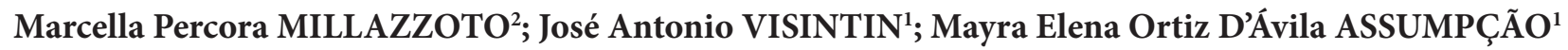 \\ ${ }^{1}$ Department of Animal Reproduction, School of Veterinary Medicine and Animal Sciences, \\ University of São Paulo, São Paulo - SP, Brasil \\ ${ }^{2}$ Center of Natural and Human Sciences, Federal University of ABC, Santo André - SP, Brasil.
}

\begin{abstract}
Protamines (PRM) are the major DNA-binding proteins in the sperm nucleus and can pack the DNA into less than 5\% of the volume of a somatic cell nucleus. It is already known that bulls only have the PRM1 protein on mature spermatozoa while most mammals also have the PRM2. Transition nuclear proteins (Tnps) and PRMs are fundamental to DNA integrity. It has already been reported the influence of PRM on chromatin structures, generating low fertility. However, molecular mechanisms underlying these effects are not known. The relative expression of PRM1, PRM2, PRM3, Tnp1 and Tnp2 was determined by real time RT-PCR, using bovine specific primers and $\beta$-actin as endogenous control. Quantification of mRNA relative expression showed a higher expression of PRM1 compared to the other genes. The PRM3 mRNA had the lowest relative expression. A significant $(\mathrm{p}<0.05)$ and positive correlation was found between PRM1 and PRM2 $(r=0.518)$, PRM2 and Tnp1 $(r=0.750)$, PRM2 and Tnp2 $(r=0.706)$, PRM3 and Tnp1 $(r=0.542)$, PRM3 and Tnp2 $(r=0.731)$ and between Tnp1 and Tnp2 $(r=0.820)$. Since most of the knowledge about protamine 2 in bovine is based on a work from 1990 and according to new studies we know that PRM1 and PRM2 are important to bull fertility, more research is needed to elucidate the real function of protamines on bovines.
\end{abstract}

Keywords: Bull. Spermatozoa. Protamine. Real time RT-PCR.

\begin{abstract}
Resumo
Protaminas (PRM) são as principais proteínas ligantes do DNA espermático e podem compactar o núcleo do espermatozoide em menos de $5 \%$ do volume de uma célula somática. Já se sabe que o touro produz apenas a PRM1 em espermatozoide maduro, enquanto a maioria dos mamíferos também produz a PRM2. As proteínas nucleares de transição (Tnps) e as PRMs são fundamentais para a integridade do DNA. Já foi descrita a influência das protaminas na estrutura da cromatina e a associação destas com a fertilidade. Entretanto, os mecanismos moleculares que geram mudanças na cromatina espermática são desconhecidos. A expressão relativa da PRM1, PRM2, PRM3, Tnp1 e Tnp2 foi determinada para dez testículos de touros oriundos de matadouros comerciais, utilizando a técnica de RT-PCR em tempo real, com primers específicos para bovinos e a $\beta$-actina como controle endógeno. Ao quantificar a expressão relativa do RNAm, detectou-se alta expressão relativa da PRM1, em comparação aos outros genes. A expressão relativa da PRM3 foi a menor de todos os genes. Foram encontradas correlações positivas e significantes $(p<0,05)$ entre PRM1 e PRM2 $(\mathrm{r}=0,518)$, PRM2 e Tnp1 $(\mathrm{r}=0,750)$, PRM2 e Tnp2 $(\mathrm{r}=0,706)$, PRM3 e Tnp1 $(\mathrm{r}=0,542)$, PRM3 e Tnp2 ( $\mathrm{r}=0,731)$ e entre Tnp1 e Tnp2 $(r=0,820)$. Visto que a maioria dos conhecimentos sobre a PRM2 estão baseados em um trabalho de 1990 e, de acordo com recentes estudos se sabe que a PRM1 e a PRM2 são importantes para a fertilidade do touro, mais estudos são necessários para determinar a real função das protaminas em touros.
\end{abstract}

Palavras-chave: Touro. Testículo. Protamina. RT-PCR em tempo real.

\section{Introduction}

Subfertility in bulls represents a great economic loss for livestock breeders. Despite its millions of dollars of economic impact, there are no reliable molecular biomarkers that can adequately predict the fertility of ejaculates. Identifying specific molecular markers and mechanisms regulating fertility is of paramount

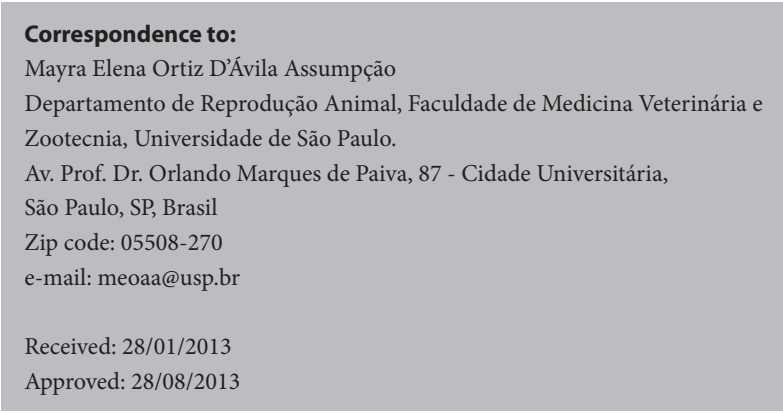

Departamento de Reprodução Animal, Faculdade de Medicina Veterinária e

Zootecnia, Universidade de São Paulo.

Av. Prof. Dr. Orlando Marques de Paiva, 87 - Cidade Universitária,

Paulo, SP, Brasi

Zip code: 05508-27

Received: $28 / 01 / 2013$

Approved: 28/08/2013 
importance. The use of semen with high quality is essential for the success of biotechnologies of reproduction such as artificial insemination, embryo transfer and in vitro fertilization. Thus, establishing new techniques that can accurately predict the bull fertility is fundamental to improve efficiency of livestock reproduction.

Male infertility is characterized by a diminished or absent ability of spermatozoa to fertilize the oocyte and support early embryonic development. Techniques routinely used to evaluate bull fertility, such as sperm concentration, morphology and motility cannot reliably predict the fertility of the bull, because features such as the quality of the genetic material are not determined by these routine assessments. In general, molecular defects including sperm DNA damage do not change morphology, motility or sperm concentration and these cells can penetrate the oocyte. However, they fail to initiate the sequence of a normal embryo development (EID; LORTON; PARRISH, 1994) and apoptosis is induced after early cleavages (FATEHI et al., 2006).

Studies analyzing the transcriptome of spermatozoa from bulls of high and low fertility in vivo, demonstrated that protamine 1 (PRM1) was one of the most expressed genes and there was a tendency of decreased expression of this gene in low fertility bulls (FEUGANG et al., 2010). In a spermatozoa proteomic analysis of bulls of varying fertility, it was demonstrated that bulls of low fertility in vivo show lower abundance of PRM1 protein compared to bulls of higher fertility (PEDDINTI et al., 2008).

Protamines are the major DNA-binding proteins in the sperm nucleus and can pack the DNA into less than $5 \%$ of the volume of a somatic cell nucleus in most vertebrates (DONNELLY et al., 2000). During spermiogenesis, haploid spermatids undergo complex morphological and physiological changes to differentiate into spermatozoa (GRZMIL et al., 2008). These processes include chromatin remodelling mediated by the replacement of histones through protamines (PRM) and transition nuclear proteins (Tnps). Inactivation of Tnps in mice generates a sub fertile phenotype, showing less condensed sperm nuclei and elevated level of breaks in the DNA strand and other morphology defects (YU et al., 2000).

The mechanisms involved on integrity and protamination of bovine spermatozoa chromosome are still poorly understood. It is known that protamines influence chromatin structures, and that chromosomal microdeletions, aneuploidy and DNA fragmentation cause low fertility in humans (ESTERHUIZEN et al., 2000). Expression levels of PRM1 have been correlated with the DNA damage in mice (SUGANUMA; YANAGIMACHI; MEISTRICH, 2005), however, its role on bull fertility is still unclear.

Studies performed on spermatozoa transcriptome and proteome showed that the ability of spermatozoa to fertilize an oocyte is a complex process that involves different molecular mechanisms; and there are many important gaps in the basic knowledge that must be clarified. The aim of this study was to determine the relative expression of PRM1, PRM2, PRM3, Tnp1 and Tnp2 in bovine testis. Evaluate the expression of these genes in the bull testis is of utmost importance to understand the role of each protamine during bull spermatogenesis.

\section{Material and methods}

\section{Tissue sampling, RNA extraction and cDNA synthesis}

Testis from post-pubertal bulls $(\mathrm{n}=10)$ were obtained from a commercial slaughterhouse (Piracicaba-SP, Brazil) and transported at $37^{\circ} \mathrm{C}$ in a thermal recipient to laboratory. After three washes with Dulbecco's Phosphate Buffer Saline (DPBS - Nutricell ${ }^{\circledR}$, Campinas, $\mathrm{SP}$, Brazil) at $37^{\circ} \mathrm{C}, 5 \mathrm{~cm}$ cranial to the epididymis tail and $4 \mathrm{~cm}$ from the medial margin of the testis, $30 \mathrm{mg}$ were removed from each testis and frozen at $-80^{\circ} \mathrm{C}$ until use.

Total RNA was extracted using the commercial kit RNAspin Mini RNA isolation Kit (GE Healthcare, 
United Kingdom), following the manufacturer's instructions. Aliquots of RNA were used for a "No-RT" PCR reaction using intron-spanning bovine protamine (PRM) 1 primers, followed by a gel electrophoresis to check for genomic DNA contamination. Total RNA quantity and purity were determined using the ND1000 spectrophotometer (NanoDrop Technologies, USA) and samples were stored immediately at $-20^{\circ} \mathrm{C}$ until synthesis of the complementary DNA (cDNA). A RNA isolation $(n=1)$ was performed for each testis $(n=10)$ with a total of 10 RNA samples.

The cDNA synthesis was performed using $8 \mu \mathrm{L}$ of total RNA, obtained as described above, by using the commercial kit First Strand Synthesis Superscript II (Invitrogen, California, United States), following the manufacturer's instructions. Total cDNA quantity and purity were determined using the ND-1000 spectrophotometer and the samples were stored immediately at $-20^{\circ} \mathrm{C}$, until use.

\section{Primers design and real time RT-PCR reactions}

For the analysis of expression of PRM1, PRM2, PRM3, Tnp1, Tnp2 and $\beta$-actin transcripts, specific primers for these genes in cattle were designed using the software Primer3 (Whitehead Institute for Biomedical Research, Unites States), based on their sequences from GenBank (Table 1).

Real time RT-PCR reaction was performed using the Platinum SYBR GreenERqPCR Super mix

Table 1 -Primers used for the real time RT-PCR analysis

\begin{tabular}{|c|c|c|}
\hline $\begin{array}{l}\text { Gen } \\
\text { (GenBank) }\end{array}$ & $\begin{array}{l}\text { Access } \\
\text { number }\end{array}$ & Primers sequence 5'- 3' \\
\hline PRM1 & BC108207 & $\begin{array}{l}\text { forward: 5'- agataccgatgctcctcacc - } 3^{\prime} \\
\text { reverse: } 5^{\prime} \text {-gcagcacactctcctcctg- 3' }\end{array}$ \\
\hline PRM2 & BC109783 & $\begin{array}{l}\text { forward: 5' - agacacaggagccacacg- } 3^{\prime} \\
\text { reverse: } 5^{\prime} \text { - ggatgtggtatgctcttcgag- } 3 \text { ' }\end{array}$ \\
\hline PRM3 & BC108198 & $\begin{array}{l}\text { forward: 5'- gaagaagctcgtggcctgt- } 3^{\prime} \\
\text { reverse: } 5^{\prime} \text { - tcaggagtgtgtctgcttgg- } 3 \text { ' }\end{array}$ \\
\hline Tnp1 & BC102598 & $\begin{array}{l}\text { forward: } 5^{\prime} \text { - attaaagagtcagggcatgagg- } 3^{\prime} \\
\text { reverse: } 5^{\prime} \text { - ctactcttcaggctgctcttcc- } 3^{\prime}\end{array}$ \\
\hline Tnp2 & BC109800 & $\begin{array}{l}\text { forward: } 5^{\prime} \text { - ggtctacgggaggactcaca - } 3^{\prime} \\
\text { reverse: } 5^{\prime} \text { - tcctcctcctcctcatcctt - 3' }\end{array}$ \\
\hline$\beta$ actin & ВТ030480 & $\begin{array}{l}\text { forward: 5'- gtccaccttccagcagatgt - 3' } \\
\text { reverse: } 5 \text { ' - gtcaccttcaccgttccagt - 3' }\end{array}$ \\
\hline
\end{tabular}

(Invitrogen, California, United States); a total of $10 \mathrm{ng}$ cDNA solution $(1 \mu \mathrm{L})$ was used in a $25 \mu \mathrm{L}$ reaction mix that consisted of $12.5 \mu \mathrm{L}$ of SyberGreenERqPCR super mix, $2 \mu \mathrm{L}$ of forward primer, $2 \mu \mathrm{L}$ of reverse primer and $7.5 \mu \mathrm{L}$ of deionized water (SigmaAldrich, USA).

Twelve PCR reactions were performed for each cDNA sample (6 genes in duplicate) in each of the 10 cDNA samples. Cycling parameters were $50^{\circ} \mathrm{C}$ for 2 $\min , 95^{\circ} \mathrm{C}$ for $30 \mathrm{~min}, 45 \mathrm{cycles}$ of $95^{\circ} \mathrm{C}$ for $15 \mathrm{~s}, 58^{\circ} \mathrm{C}$ for $15 \mathrm{~s}$ and for $20 \mathrm{~s}$ for amplification and extension. The melting curve was performed starting at $95^{\circ} \mathrm{C}$ for $15 \mathrm{~s}, 60^{\circ} \mathrm{C}$ for $15 \mathrm{~s}$ and an increase of the temperature to $95^{\circ} \mathrm{C}$ in $20 \mathrm{~min}$.

\section{Statistical analysis}

The relative amount of PCR products generated from each primer set was determined using a Relative Expression Software Tool (PFAFFL, 2004) based on the expression of the endogenous control ( $\beta$-actin). When analyzing the relative expression by REST a Pair Wise Fixed Reallocation Randomization Test is used, showing the variation in the relative expression when comparing the different genes (PFAFFL; HORGAN; DEMPFLE, 2002). Furthermore the correlation between the relative expression of PRM1, PRM2, PRM3, Tnp1 and Tnp2 were investigated through linear regression analyses (Pearson correlation), the significance level $(\alpha)$ for the model was 0.05 .

\section{Results}

The protocol employed for the total RNA extraction allowed isolation of high quantity $(\sim 109.710 \pm 63.873$ $\eta \mathrm{g} / \mu \mathrm{l})$ and high quality $\left(\mathrm{A}_{260 / 280 \mathrm{~nm}}\right.$ ranging from 2.11 to 2.19) testicular total RNA. The isolation of RNA free of genomic DNA contamination was evaluated through "No-RT" PCR of the PRM1 gene. The amplification of total RNA samples did not generate any amplicons, indicating no genomic DNA contamination. Specificity of RT-PCR products was documented with gel electrophoresis and resulted in a single product with the desired length (PRM1, 112 
bp; PRM2, 193 bp; PRM3, 178 bp; Tnp1, 114 bp and Tnp2, 100 bp). Real-time PCR efficiencies (E) were calculated according to the equation: $\mathrm{E}=10^{(-1 / \text { slope })}$. Investigated transcripts showed real-time efficiency rates for PRM1 (E = 1.95), PRM2 (E = 1.93), PRM3 $(\mathrm{E}=1.84)$, Tnp1 $(\mathrm{E}=1.88)$, Tnp2 $(\mathrm{E}=1.95)$ and $\beta$-actin $(E=1.84)$ in the investigated range $5,10,20,40$ and 80 ng cDNA input.

Real time RT-PCR was performed on total cDNA prepared from 10 testis of post-pubertal bulls. The results for each testis are shown on Table 2. When comparing the relative expression without considering each testis separately, a higher expression of PRM1 was observed $(\mathrm{P}<0.05)$. The relative expression of PRM2 was lower than the relative expression of PRM1 $(p<0.05)$. There was no difference between the relative expression of PRM2, Tnp1 and Tnp2 ( $p>0.05)$. The relative expression of PRM2 was significantly higher than the relative expression of PRM3 $(p<0.05)$.

A significant $(\mathrm{p}<0.05)$ and positive correlation was found between PRM1 and PRM2 ( $r=0.518)$, PRM2 and Tnp1 $(\mathrm{r}=0.750)$, PRM2 and Tnp2 $(\mathrm{r}=0.706)$, PRM3 and Tnp1 $(\mathrm{r}=0.542)$, PRM3 and Tnp2 $(\mathrm{r}=0.731)$ and between Tnp1 and Tnp2 $(\mathrm{r}=0.820)($ Figure 1$)$.

Table 2 - Relative expression of Protamine 1 (PRM1), Protamine 2 (PRM2), Protamine 3 (PRM3), Transition nuclear protein 1 (Tnp1) and Transition nuclear protein 2 (Tnp2), for 10 Bovine testis and the ratio PRM1:PRM2

\begin{tabular}{lcccccc}
\hline Testis & \multicolumn{4}{c}{ Relative expression by using $\beta$-actin } & $\begin{array}{c}\text { Ratio } \\
\text { as endogenous control }\end{array}$ \\
\cline { 2 - 5 } & PRM1 & PRM2 & PRM3 & Tnp1 & Tnp2 & \\
\hline 1 & 24.55 & 6.68 & 2.65 & 6.96 & 9.12 & 3.67 \\
2 & 20.56 & 5.74 & 5.90 & 6.39 & 10.19 & 3.58 \\
3 & 36.22 & 9.51 & 3.35 & 7.93 & 10.09 & 3.80 \\
4 & 21.19 & 4.95 & 1.73 & 3.95 & 4.12 & 4.28 \\
5 & 29.23 & 5.20 & 1.20 & 5.76 & 6.91 & 5.62 \\
6 & 13.75 & 2.47 & 1.40 & 4.07 & 0.97 & 5.56 \\
7 & 22.81 & 5.06 & 2.16 & 6.27 & 3.89 & 4.50 \\
8 & 28.26 & 5.43 & 2.26 & 5.77 & 4.84 & 5.21 \\
9 & 39.65 & 4.17 & 1.35 & 3.15 & 2.18 & 9.52 \\
10 & 27.43 & 7.07 & 1.84 & 5.10 & 3.65 & 3.88 \\
\hline
\end{tabular}

\section{Discussion}

It was presented the relative expression of the PRM1, PRM2, PRM3, Tnp1 and Tnp2 mRNA in bovine testicles. In humans and mice is well established the role of Tnps and protamines on DNA compaction, and changes in the DNA packing generate failures on embryonic development. It is unclear whether it occurs in cattle, since the literature about this process in bovine testicle is scarce, being mostly based on a work from 1990 (MAIER et al., 1990) in which the authors reports a mutation in the PRM2 gene and that the PRM2 is not found in mature sperm. A recent study has shown the expression of PRM1 and PRM2 in crossbreed Frieswal bull spermatozoon, showing that good quality semen producing group had higher PRM1 transcripts than the poor quality semen producer (GANGULY et al., 2013). They also found that there is no difference on sperm PRM2 transcripts between the good and poor quality group. Although, no PRM2 expression were found when analyzing $B$. Taurus spermatozoa (HECHT et al., 2011).

Abnormal protein synthesis has been reported to be associated with aberrant mRNA retention suggesting that defects in protamine translational regulation may contribute to protamine deficiency in infertile men (AOKI et al., 2006). The PRM1/PRM2 rate is important for predicting fertility in humans. Changes in PRM1/ PRM2 ratio may be the result of widespread failure in the replacement of histones by protamines during men spermiogenesis (OLIVA, 2006). In humans, most of the infertility cases caused by protamine deficiency are related to PRM2. For men the PRM1/ PRM2 ratio should be maintained at 1:1 and changes in this ratio can affect motility, concentration, morphology, sperm penetration capacity, leading to sperm fragmentation (AOKI et al., 2006). The PRM1/ PRM2 ratio found for bull in this study ranged from 3.58 to 9.52 , indicating that this species has a lower expression of PRM2 relative to PRM1. It was found that the DNA fragmentation rate in bovine sperm is quite modest compared to those for humans. Rates 

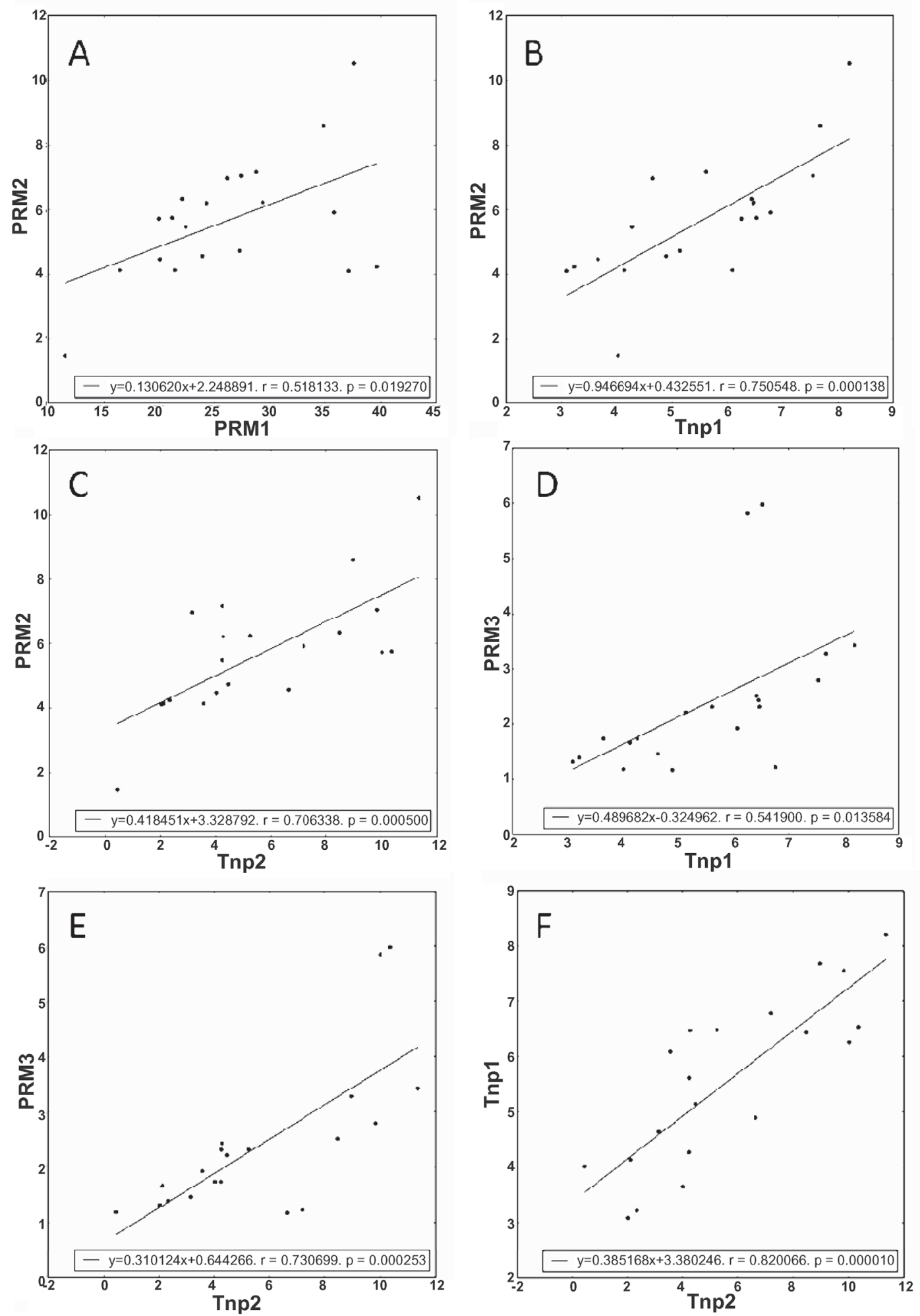

Figure 1 - Pearson's correlation, scatter plot and regression line for (A) PRM1 and PRM2, (B) PRM2 and Tnp1, (C) PRM2 and Tnp2, (D) PRM3 and Tnp1, (E) PRM3 and Tnp2 and (F) Tnp1 and Tnp2 in the bovine testis. ( $\mathrm{r}=$ correlation coefficient, $\mathrm{y}=$ regression equation, $\mathrm{p}$ is significant at a 0.05 level) 
of sperm DNA fragmentation in cattle are less than $15 \%$, even in animals with compromised reproductive history (BOCHENEK; SMORAG; PILCH, 2001). In contrast, in humans, the rates that affect male fertility are more than $25 \%$. This reduced fragmentation rate in bulls compared to humans may be explained by the fact that bulls have a lowest amount of PRM2 compared to the amount of PRM1.

It is important to highlight that bovine suffer from intense selection pressure since its domestication, dating from the Neolithic period $(10,000$ BC to 3,000 BC) (FOOTE, 2002). With this long period of genetic selection, possible changes in the bovine protamination process may have occurred, in which PRM2 could be involved only in some specific points of DNA compression during spermatogenesis and are not necessarily found in the chromatin of the ejaculated sperm. Showing that, differently from human and mice, the lower expression of PRM2 mRNA may be an evolutionary adaptation of the bull sperm, which makes the bovine sperm less susceptible to protamination changes that lead to infertility.

The role of PRM3 on bull spermatozoa is still not elucidated, and this is the first study that showed the expression of this gene on bovine testis. Analysis of a mouse knockout for the PRM3 gene (PRM3 ${ }^{-/}$) demonstrated that mice lacking the PRM3 protein are fertile, despite the decrease in sperm motility (GRZMIL et al., 2008). The role of Tnps in bulls are also unclear, it is known that these proteins are important to the chromatin integrity in mice, because the inactivation of Tnp2 in mice leads to failure in the PRM2 transduction and a subfertile phenotype, showing less condensed sperm nuclei, and elevated level of breaks in the DNA (YU et al., 2000).

When the correlation was performed, a positive and significant correlation was found between the genes, excluding PRM1 that was correlated just with the PRM2, and the PRM3 that was not correlated with PRM2 neither PRM1. The presence of a significant correlation between the genes shows that the expression of these genes are not an individual process during the spermatogenesis, and that changes in this interaction may cause loss of fertility, as demonstrated in mice (YU et al., 2000; ZHAO et al., 2001) and human (AOKI et al., 2006; TORREGROSA et al., 2006) .

Therefore, more studies should be performed to evaluate the function of these proteins in bull. It is fundamental to understand the biology of bovine spermiogenesis, providing knowledge to increase the fertility, and be able to elucidate the evolutionary mechanisms that may have caused the possible loss of functionality of PRM2 in bull spermatozoa. A detailed knowledge about the protamination process in bovine sperm can help to understand the enhanced susceptibility to sperm DNA fragmentation in humans, since the bull sperm chromatin appears to be more resistant to DNA damage.

\section{Acknowledgements}

This work was supported financially by FAPESP (09/17035-6 and 07/55294-8). 


\section{References}

AOKI, V. W.; EMERY, B. R.; LIU, L.; CARRELL, D. T. Protamine levels vary between individual sperm cells of infertile human males and correlate with viability and DNA integrity. Journal of Andrology, v. 27, n. 6, p. 890-898, 2006.

AOKI, V. W.; LIU, L.; CARRELL, D. T. A novel mechanism of protamine expression deregulation highlighted by abnormal protamine transcript retention in infertile human males with sperm protamine deficiency. Molecular Human Reproduction, v. 12 , n. 1 , p. $41-50,2006$

BOCHENEK, M.; SMORAG, Z.; PILCH, J. Sperm chromatin structure assay of bulls qualified for artificial insemination. Theriogenology, v. 56, n. 4, p. 557-567, 2001.

DONNELLY, E. T.; O'CONNELL, M.; MCCLURE, N.; LEWIS, S. E. Differences in nuclear DNA fragmentation and mitochondrial integrity of semen and prepared human spermatozoa. Human Reproduction, v. 15, n. 7, p. 1552-1561, 2000.

EID, L. N.; LORTON, S. P.; PARRISH, J. J. Paternal influence on S-phase in the first cell cycle of the bovine embryo. Biology of Reproduction, v. 51, n. 6, p. 1232-1237, 1994.

ESTERHUIZEN, A. D.; FRANKEN, D. R.; LOURENS, J. G.; PRINSLOO, E.; VAN ROOYEN, L. H. Sperm chromatin packaging as an indicator of in-vitro fertilization rates. Human Reproduction, v. 15, n. 3, p. 657-661, 2000.

FATEHI, A. N.; BEVERS, M. M.; SCHOEVERS, E.; ROELEN, B. A.; COLENBRANDER, B.; GADELLA, B. M. DNA damage in bovine sperm does not block fertilization and early embryonic development but induces apoptosis after the first cleavages. Journal of Andrology, v. 27, n. 2, p. 176-188, 2006.

FEUGANG, J. M.; RODRIGUEZ-OSORIO, N.; KAYA, A.; WANG, H.; PAGE, G.; OSTERMEIER, G. C.; TOPPER, E. K.; MEMILI, E. Transcriptome analysis of bull spermatozoa: implications for male fertility. Reproductive Biomedicine Online, v. 21, n. 3, p. 312-324, 2010.

FOOTE, R. H. The history of artificial insemination: selected notes and notables. Journal of Animal Science, v. 80, p. 1-10, 2002.

GANGULY, I.; GAUR, G. K.; KUMAR, S.; MANDAL, D. K.; KUMAR, M.; SINGH, U.; KUMAR, S.; SHARMA, A. Differential expression of protamine 1 and 2 genes in mature spermatozoa of normal and motility impaired semen producing crossbred Frieswal $(\mathrm{HF} \times \mathrm{Sahiwal})$ bulls. Research in Veterinary Science, v. 94 , n. 2, p. 256-262, 2013.

GRZMIL, P.; BOINSKA, D.; KLEENE, K. C.; ADHAM, I.; SCHLÜTER, G.; KÄMPER, M.; BUYANDELGER, B.; MEINHARDT, A.; WOLF, S.; ENGEL, W. Prm3, the fourth gene in the mouse protamine gene cluster, encodes a conserved acidic protein that affects sperm motility. Biology of Reproduction, v. 78, n. 6, p. 958-967, 2008.

HECHT, N.; CAVALCANTI, M.C.O.; NAYUDU, P.; BEHR, R.; REICHENBACH, M.; WEIDNER, W.; STEGER, K. Protamine-1 represents a sperm specific gene transcript: a study in Callithrix jacchus and Bos taurus. Andrologia, v. 43, n. 3, p. 167-73, 2011.

MAIER, W. M.; NUSSBAUM, G.; DOMENJOUD, L.; KLEMM, U.; ENGEL, W. The lack of protamine 2 (P2) in boar and bull spermatozoa is due to mutations within the P2 gene. Nucleic Acids Research, v. 18, n. 5, p. 1249-1254, 1990.

OLIVA, R. Protamines and male infertility. Human Reproduction Update, v. 12, n. 4, p. 417-435, 2006.

PEDDINTI, D.; NANDURI, B.; KAYA, A.; FEUGANG, J. M.; BURGESS, S. C.; MEMILI, E. Comprehensive proteomic analysis of bovine spermatozoa of varying fertility rates and identification of biomarkers associated with fertility. BMC Systems Biology, v. 2, p. 19, 2008.

PFAFFL, M. W. Quantification strategies in real-time PCR. In: BUSTIN, S. A. (Ed). A-Z of quantitative PCR. California: IUL Biotechnology Series, 2004. cap. 3, p. 87-112.

PFAFFL, M. W.; HORGAN, G. W.; DEMPFLE, L. Relative expression software tool (REST) for group-wise comparison and statistical analysis of relative expression results in real-time PCR. Nucleic Acids Research, v. 30, n. 9, p. e.36, 2002.

SUGANUMA，R.; YANAGIMACHI， R.; MEISTRICH，M. L. Decline in fertility of mouse sperm with abnormal chromatin during epididymal passage as revealed by ICSI. Human Reproduction, v. 20, n. 11, p. 3101-3108, 2005.

TORREGROSA, N.; DOMÍNGUEZ-FANDOS, D.; CAMEJO, M. I.; SHIRLEY, C. R.; MEISTRICH, M. L.; BALLESCÂ, J. L.; OLIVA, R. Protamine 2 precursors, protamine 1 /protamine 2 ratio, DNA integrity and other sperm parameters in infertile patients. Human Reproduction, v. 21, n. 8, p. 2084-2089, 2006.

YU, Y. E.; ZHANG, Y.; UNNI, E.; SHIRLEY, C. R.; DENG, J. M.; RUSSELL, L. D.; WEIL, M. M.; BEHRINGER, R. R.; MEISTRICH, M. L. Abnormal spermatogenesis and reduced fertility in transition nuclear protein 1-deficient mice. Proceedings of the National Academy of Sciences of the United States of America, v. 97, n. 9 , p. $4683-4688,2000$.

ZHAO, M.; SHIRLEY, C. R.; YU, Y. E.; MOHAPATRA, B.; ZHANG, Y. U. N.; UNNI, E.; DENG, J. M.; ARANGO, N. A.; TERRY, N. H. A.; WEIL, M. M.; RUSSELL, L. D.; BEHRINGER, R. R.; MEISTRICH, M. L. Targeted Disruption of the Transition Protein 2 Gene Affects Sperm Chromatin Structure and Reduces Fertility in Mice. Molecular and Cellular Biology, v. 21, n. 21, p. 7243-7255, 2001. 